\section{Leafminer-resistant Spinach Germplasm 03-04-63}

\author{
Beiquan Mou, ${ }^{1,2}$ \\ U.S. Department of Agriculture, Agricultural Research Service, 1636 East \\ Alisal Street, Salinas, CA 93905
}

Additional index words. Liriomyza langei, insect resistance, Spinacia oleracea, germplasm

Leafminers are important insect pests of many agricultural crops throughout the world (Parrella, 1987), including spinach (Spinacia oleracea L.). The predominant species in the spinach production areas in central California is Liriomyza langei (Scheffer et al., 2001). Leafminer adults are small, shiny black flies that puncture leaves to feed on plant sap, whereas females lay white, oval eggs within the leaf tissue, resulting in "stings" that appear as holes or bumps on the leaves. Larvae hatch from eggs and feed between upper and lower leaf surfaces leaving winding, whitish tunnels (mines) that are initially narrow but increase in width as the larvae grow. After completing three instars, larvae emerge from mines and pupate in cracks in the soil or on the leaf surface, and adult flies emerge from pupae in $\approx 8$ to $11 \mathrm{~d}$. The entire life cycle can be completed in less than 3 weeks and many generations are produced each year in California. Damage incited by adult stings and larval mining of leaves reduces photosynthetic capacity, renders spinach leaves unmarketable, and provides an entrance for disease organisms (LeStrange et al., 1999).

Chemical control of leafminers usually lasts only a short time. Adult control with contact insecticides is especially unsatisfactory because flies are moving targets and any treated field is subject to reinfestation from adjacent untreated crops and weeds (LeStrange et al., 1999). Many studies have shown that leafminers can develop a high degree of resistance to a broad range of insecticides (Keil and Parrella, 1990; Mason et al., 1987; Parrella and Trumble, 1989). In California, chemical control is often not an option for spinach. Fresh market "baby leaves" are harvested in $\approx 24 \mathrm{~d}$ from planting (at the four- to five-leaf stage) with "junior leaves" harvested several days later. Many systemic insecticides for larval control have a require-

\footnotetext{
Received for publication 25 May 2007. Accepted for publication 24 June 2007.

We thank JoAnn Tanaka and Sharon Benzen for technical assistance and Wenqiang Zhai and Michael Courtney for critical review and discussion of the manuscript. We also thank the North Central Regional Plant Introduction Station, Iowa State University, Ames, IA, for providing seeds of the spinach collection for this research.

${ }^{1}$ Research Geneticist.

${ }^{2}$ To whom reprint requests should be addressed; e-mailbmou@pw.ars.usda.gov.
}

ment of a 14-d preharvest spray interval (the period before harvest when no spray is allowed). The result is that a "baby leaf" field has to be sprayed $\approx 10$ or fewer days after planting when plants are still small and most of the spray is wasted. Some growers try to avoid leafminers by planting spinach in fields where the insect pressure is low, but leafminer infestation is often unpredictable. As a result, spinach is often tainted with the stipples of adult stings or mines from feeding larvae, thus reducing quality, appearance, and value. Therefore, it is essential to develop alternative management strategies for leafminers.

Resistant cultivars remain the most economical means of insect control. Their use may cut down the costs of chemicals, energy, and labor associated with pesticide spray, reduce workers' exposure to hazardous chemicals, and decrease insecticide residues on plants, resulting in increased consumer possible pesticide contamination of soil and groundwater. However, spinach cultivars with high levels of resistance to leafminers are not currently available. With the rising demand and increasing production of spinach products, there is an urgent need to develop leafminer resistance in spinach. In this article, the development of a leafminer-resistant spinach breeding line is described.

\section{Origin}

The research was conducted at the experiment station of the U.S. Department of ach collection (332 accessions) from the National Plant Germplasm System, USDA [North Central Regional Plant Introduction (PI) Station, Iowa State University, Ames, IA], was screened for leafminer resistance in a preliminary field study in 2002 (B. Mou, unpublished data). No accession was immune to leafminers, but partial resistance was found in individual plants within some accessions. A recurrent selection method was used to increase the level of resistance to leafminers. Eight plants with fewer leafminer mines were selected from six accessions (two plants from both PI 169673 and PI 370602; one plant each from PI 220121, PI 531457, PI 604787, and NSL 6085) and were moved into an isolator (a small greenhouse) for crosspollination of each other in 2002. Approximately 400 seeds harvested from acceptance of spinach. It may also reduce Agriculture (USDA), Salinas, CA. The spin- these plants were planted in the field in 2003 for another round of selection. Thirtytwo plants with fewer leafminer mines were selected and allowed to pollinate each other in isolation. Seeds were harvested from these plants to produce the breeding line 03-04-63.

\section{Description}

Insect resistance. The breeding line 0304-63 was planted in a field at the Hartnell College in July 2004 (Trial 1) and at the experiment station of the USDA in Aug. 2004 (Trial 2), Aug. 2005 (Trial 3), and Aug. 2006 (Trial 4) in Salinas, CA, to evaluate its resistance to leafminers. Commercial spinach cultivars 'Hellcat' (Seminis Vegetable Seeds, Woodland, CA), 'Lion' (Rijk Zwaan, De Lier, Holland), 'Nordic IV' and 'Springfield' (Gowan Seed Co., Salinas, CA) were included in the trials. The experiment design was a randomized complete block with eight replications. Each plot consisted of 10 plants of a genotype with $30 \mathrm{~cm}$ between plants and $35 \mathrm{~cm}$ between rows on $1-\mathrm{m}$ wide double-row beds. Numbers of leafminer mines on each plant were counted 6 weeks after planting. Plant weight excluding roots was also determined for each plant. Per-plant values were averaged and analysis was conducted on the plot mean basis. Data were analyzed by analysis of variance using the general linear model procedure of JMP v. 5 (SAS Institute, Cary, NC) with genotypes as fixed effects and replications as random effects. For comparisons between genotypes, least significant differences were calculated with an error rate of $P=0.05$.

Breeding line 03-04-63 had significantly fewer leafminer mines per plant than the commercial cultivars tested (Table 1). 0304-63 had 16.1, 13.1, 4.1, and 4.3 mines per plant in Trials 1, 2, 3, and 4, respectively, whereas commercial cultivars averaged 127.2, 67.2, 54.7, and 46.7 mines per plant in the four trials, respectively. Because 0304-63 had lower plant weight than the cultivars, mines per plant were divided by plant weight to derive mines per $100 \mathrm{~g}$ plant weight. Breeding line 03-04-63 still showed significantly fewer mines per unit plant weight than the cultivars. 03-04-63 had $17.8,7.5,7.8$, and 26.3 mines per $100 \mathrm{~g}$ plant weight in Trials 1, 2, 3, and 4, respectively, compared with the averages of $61.2,30.5$, 54.9 , and 76.4 mines per $100 \mathrm{~g}$ for commercial cultivars in the four trials, respectively. Although 03-04-63 is resistant to mines, it was not resistant to damage from leafminer stings based on field observations.

Morphological characters. 03-04-63 is a semiflat type with dark green, semierect leaves (Fig. 1). Its leaf shape is ovate and there may be one or two indents on both sides of the leaf blade. It has a dioecious flowering habit and produces smooth seeds. It has moderate resistance to bolting as compared with other germplasm accessions. It was found to be susceptible to downy mildew (Peronospora farinose f. sp. spinaciae) in the 
Table 1. Means and least significant differences (LSD) at $P=0.05$ for leafminer mines of spinach cultivars and breeding line evaluated in field trials in Salinas, CA, in 2004 (Trials 1 and 2), 2005 (Trial 3), and 2006 (Trial 4).

\begin{tabular}{|c|c|c|c|c|c|c|c|c|c|c|c|c|}
\hline \multirow[b]{2}{*}{ Genotype } & \multicolumn{4}{|c|}{ Plant $w^{z}(g)$} & \multicolumn{4}{|c|}{ Mine/plant } & \multicolumn{4}{|c|}{ Mine/100 $\mathrm{g} \mathrm{wt}^{\mathrm{y}}$} \\
\hline & Trial 1 & Trial 2 & Trial 3 & Trial 4 & Trial 1 & Trial 2 & Trial 3 & Trial 4 & Trial 1 & Trial 2 & Trial 3 & Trial 4 \\
\hline Lion & $201.2 \mathrm{a}$ & $212.4 \mathrm{a}$ & $96.3 \mathrm{a}$ & $60.5 \mathrm{a}$ & $156.5 \mathrm{a}$ & $71.2 \mathrm{a}$ & $60.6 \mathrm{a}$ & $49.7 \mathrm{a}$ & $78.3 \mathrm{a}$ & $35.7 \mathrm{a}$ & $66.5 \mathrm{a}$ & $87.4 \mathrm{a}$ \\
\hline Hellcat & $198.4 \mathrm{a}$ & $197.4 \mathrm{a}$ & $97.9 \mathrm{a}$ & $67.8 \mathrm{a}$ & $123.1 \mathrm{~b}$ & $57.8 \mathrm{a}$ & $56.6 \mathrm{ab}$ & $49.8 \mathrm{a}$ & $64.8 \mathrm{~b}$ & $31.4 \mathrm{ab}$ & $58.2 \mathrm{ab}$ & $76.9 \mathrm{ab}$ \\
\hline Nordic IV & $234.6 \mathrm{a}$ & $280.2 \mathrm{a}$ & $110.1 \mathrm{a}$ & $68.6 \mathrm{a}$ & $118.9 \mathrm{~b}$ & $75.9 \mathrm{a}$ & $44.2 \mathrm{~b}$ & $41.3 \mathrm{a}$ & $52.7 \mathrm{c}$ & $28.8 \mathrm{ab}$ & $43.2 \mathrm{c}$ & $73.0 \mathrm{ab}$ \\
\hline Springfield & $237.3 \mathrm{a}$ & $255.3 \mathrm{a}$ & $115.7 \mathrm{a}$ & $69.0 \mathrm{a}$ & $110.4 \mathrm{~b}$ & $63.7 \mathrm{a}$ & $57.3 \mathrm{a}$ & $45.8 \mathrm{a}$ & $48.9 \mathrm{c}$ & $26.2 \mathrm{~b}$ & $51.7 \mathrm{bc}$ & $68.2 \mathrm{~b}$ \\
\hline $03-04-63$ & $86.3 \mathrm{~b}$ & $91.7 \mathrm{~b}$ & $47.0 \mathrm{~b}$ & $15.8 \mathrm{~b}$ & $16.1 \mathrm{c}$ & $13.1 \mathrm{~b}$ & $4.1 \mathrm{c}$ & $4.3 \mathrm{~b}$ & $17.8 \mathrm{~d}$ & $7.5 \mathrm{c}$ & $7.8 \mathrm{~d}$ & $26.3 \mathrm{c}$ \\
\hline $\mathrm{LSD}_{0.05}$ & 53.0 & 84.1 & 29.2 & 20.4 & 21.4 & 19.6 & 12.4 & 9.4 & 10.9 & 7.3 & 9.6 & 18.5 \\
\hline
\end{tabular}

zMeans within a column followed by the same letter are not significantly different at $P=0.05$.

${ }^{\mathrm{y}}$ Number of mines per $100 \mathrm{~g}$ fresh plant weight.

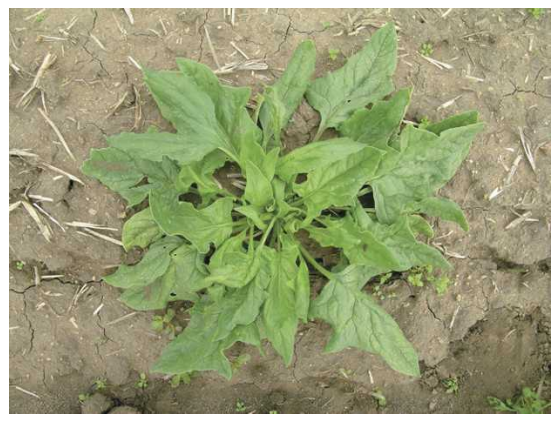

Fig. 1. A typical plant of spinach germplasm 03-04-63 in the field.

field, although the race of the pathogen was not determined.
Seed availability. Limited samples of seed are available from the author for distribution to all interested parties for research purposes, including the development and commercialization of new cultivars. Samples will also be deposited in the National Plant Germplasm System. It is requested that appropriate recognition be made if 03-04-63 germplasm contributes to research or the development of new germplasm, breeding lines, inbreds, or cultivars.

\section{Literature Cited}

Keil, C.B. and M.P. Parrella. 1990. Characterization of insecticide resistance in two colonies of Liriomyza trifolii (Diptera: Agromyzidae). J. Econ. Entomol. 83:18-26.

LeStrange, M., S. Koike, J. Valencia, and W. Chaney. 1999. Spinach production in California.
University of California, Division of Agriculture and Natural Resources, Publication 7212:3-4.

Mason, G.A., M.W. Johnson, and B.E. Tabashnik. 1987. Susceptibility of Liriomyza sativae and Liriomyza trifolii (Diptera: Agromyzidae) to permethrin and fenvalerate. J. Econ. Entomol. 80:1262-1266.

Parrella, M.P. 1987. Biology of Liriomyza. Annu. Rev. Entomol. 32:201-224.

Parrella, M.P. and J.T. Trumble. 1989. Decline of resistance in Liriomyza trifolii (Diptera: Agromyzidae) in the absence of insecticide selection pressure. J. Econ. Entomol. 82:365-368.

Scheffer, S.J., A. Wijesekara, D. Visser, and R.H. Hallett. 2001. Polymerase chain reaction-restriction fragment-length polymorphism method to distinguish Liriomyza huidobrensis from L. langei (Diptera: Agromyzidae) applied to three recent leafminer invasions. J. Econ. Entomol. 94:1177-1182. 